\title{
Watts Across the Border: Technology and the Integration of the North Amer- ican Economy in the Second Industrial Revolution ${ }^{1}$
}

\author{
James Hull, University of British Columbia
}

\section{Introduction}

Shortly after the Second World War, UK manufacturers complained that the strict Canadian Electrical Code made it difficult for them to export electrical goods to the Canadian market. Unimpressed, the editor of a Canadian technical journal allowed that "requirements are not severe and are readily met by manufacturers on the North American continent." 2 The situation had not arisen suddenly. During the war, Ford engineers travelled to England to get the technical drawings for RollsRoyce's Merlin aircraft engine, which Ford planned to mass produce in the United States. To the chagrin of their British counterparts, the engineers rejected the drawings for this purpose as the tolerances specified were far too lax for Ford's production methods. ${ }^{3}$ In fact, probably since the 1920 s the general run of manufacturing practice in North America had been in advance of England and elsewhere in Europe. But what is particularly revealing about the editorial comment is that it was not an expression of nationalistic opinion but a casual expression of continentalism. The issue was not that British practice differed from and was inferior to US and Canadian practice, but that it was different from and inferior to a common North American practice.

The Second World War has often been cited as the decisive influence which moved Canada from a British political empire to a US economic one. Massive state-directed programs like the Materials Coordinating Committee, the Joint Economic Committee, the Joint War Production Committee, and the Joint Agricultural Committee in this view reshaped the economic landscape making it more continentally integrated. ${ }^{4}$ This, however, is to confuse cause with effect. Such wartime coordination was only possible due to the existing degree of technical uniformity between Canadian and American industry. A complete account of how North American industrial practice evolved in this fashion would require a complete history of US and Canadian industry. The scope of this article is more modest. It examines, for the early twentieth century, the process by which the two countries came to share common technical practices in manufacturing and beyond in the economy. It shows that in this process, as with other aspects of economic integration, state actors in Canada enthusiastically facilitated the northward extension of the American economy, sometimes by their actions and sometimes by benevolent inaction. It shows as well the role played by members of the technical middle class - professional engineers and the like - in this process, sometimes as state agents, sometimes as corporate employees and, crucially, sometimes in the institutional framework of 
their own professional organizations. ${ }^{5}$ The process of continental integration was not then a simple, unidirectional expansion of the American economic "empire" facilitated by Canadian compradors and a supine if not collaborative political elite. ${ }^{6}$ Rather it was an active and shared process with a variety of actors pursuing individual goals and arriving at a common outcome. To show this, I will first give a very brief introduction to the historical phenomenon of the integration of the Canadian and US economies. Then I will look at the evolution of a common Canadian-American industrial practice, the technological dialogue carried on across the international border, and finally the role of a shared regime of technical standards.

The path-breaking work of Gabriel Kolko drew historians' attention to the role of government, particularly big government, in Progressive-era America in regulating industry to its own benefit. ${ }^{7}$ Ellis Hawley, one of the leaders of the so-called organizational school of American historians, has continued the story into the interwar period, describing the relations between Herbert Hoover - as Secretary of Commerce and then President - and industry-wide associations. ${ }^{8}$ What the organizational synthesis has rarely dealt with effectively is the state. Canadian historians, perhaps more comfortable with Marxist conceptions, have been more ready to put the state centre-stage in their analyses. Notably, Tom Traves has outlined how the representatives of Canadian big business found sectoral regulation of industry during the First World War rather more to their liking than not and would have been glad to see a vigorous Canadian regulatory state continue acting on their behalf. ${ }^{9}$ This study supports the view of regulatory states on both sides of the border acting hand in glove with trade associations and with engineers, architects, public health doctors, and the like to solve the technical problems of transnational capital. If Marx viewed the state in his day as the executive committee of the bourgeoisie, by the time of the Second Industrial Revolution, it might also be described as the secretariat for an alliance of trade associations.

\section{Economic Integration}

With greater drama going on in American history in the decades after the Civil War, the broadening and deepening economic relationship with Canada attracted little attention at the time and has attracted even less from most scholarly accounts of US history of the period. However, as Walter LaFeber notes, by the turn of the century policy makers at the highest level in the United States were noticing that "trade, as well as investment, was rapidly moving north." ${ }^{10}$ For the United States, not autarchic but with its own continental national economy, this relationship, like all of its external economic relationships, was significant but not crucial. Brute force imperialism with formal political control as well as Big Stick, great power hegemony could be used to secure raw materials and markets. But that can cost money and present other political costs. Canada was a useful and safe source for investment, a ready and willing market for goods that could be undifferentiated extensions of domestic production runs and a secure source, among many, of raw materials. Occa- 
sionally the latter were of more than marginal importance. ${ }^{11}$ The need for inexpensive newsprint to feed the voracious appetites of American presses obliged America to access Canadian forests largely on Canadian terms. As we shall see, this led to explicit and determined efforts to seek technological uniformity in a highly integrated continental pulp and paper industry. The nickel for the steel in imperial America's navy came out of the ground in the Sudbury basin, carted off first to New Jersey but later, at Canadian insistence, refined in Port Colborne, Ontario, bringing state-of-the art processing as well as extractive technologies (and environmental degradation) to Canada. The electrochemical industry which developed in Niagara Falls, New York relied on cheap hydroelectric power. Most of it came from across the river, generated by what became the single largest electrical utility in the world, the Hydroelectric Power Commission of Ontario. Organizationally, Ontario Hydro, a public agency, was frequently cited as a model by American Progressives and Hydro's engineers were active in the formulation of North America-wide technical standards, often through service on US committees of engineering and technical associations.

From the Canadian perspective these developments were not marginal; they were central to the country's development. Canadians were certain they wanted an independent polity but were less certain how economic propinquity might relate to that. There were false steps. Canadians at first opted for a wider railroad gauge, but the economic costs of this technological protectionism were quickly realized and track was re-laid using the American 4' 8 1/2" standard. ${ }^{12}$ In this instance integration rather than protection best fit the objectives of both Canadian and US capitalists. The Canadian national government pursued a similar development strategy. Focused on railroads, immigration and homesteading, but above all else, on a protective tariff, the National Policy was a have-your-cake-and-eat-it-too strategy visà-vis the United States. On the one hand it intended to foster an east-west rather than north-south economy, creating and maintaining an independent political economy north of the $49^{\text {th }}$ parallel. On the other hand, it had the intended effect of encouraging US manufacturing firms to jump the Canadian tariff wall and set up manufacturing facilities in Canada to supply Canadian (and sometimes wider Imperial) markets. ${ }^{13}$ And jump they did, a jump eased by very similar consumer tastes in both countries. Once domiciled, American branch plant firms happily benefitted from and indeed participated in nationalistic efforts aimed at promoting consumption by Canadians of Canadian-made goods. ${ }^{14}$ It was not commodity markets, store shelves, and capital flow alone which truly integrated the North American economy. In addition, common solutions to common technical problems of production were sought and found.

\section{A Common Industrial Practice}

The most obvious way in which American manufacturing norms came to Canada was via American production facilities built in Canada. Westinghouse, Kodak, Ford, 
and scores of other companies did not just bring dollars; they also brought technology and industrial practices to Canada that were easily implemented. Canadian industry took on an increasingly American flavour in its tools, materials, and shop practices. As Zeff notes, even Canadian accounting practices moved from British to US forms, which he attributes, in part, to the influence of US direct investment, but also to the influence of US textbooks and education models for the profession. ${ }^{15}$ In Canada both branch plant firms and domestically owned ones shared a common technical practice. At least by the interwar period contemporaries were identifying a common North American industrial standard and contrasting it favourably to that of Europe. For example, in 1928 the President of the Packard Electric Company, commenting on the possibility that European bids for transformers might be considered by the city of Winnipeg, wrote "in the long run they would be very much dissatisfied and sorry ... everything about the manufacture would be far different than on this continent," and added for good measure "we know for a fact that the electrical steel made on the continent and in England is very much poorer than any steel manufactured on this continent." ${ }^{\text {"16 }}$

A good illustration of how technical and economic integration worked in the context of broader trends in business and industry of the time is given by Gregory P. Marchildon in his study of the Portland cement industry. ${ }^{17}$ The technology of Portland cement manufacturing as well as the consolidation of a fragmented industry both came to Canada thanks to the combined efforts of Canadian and American industrialists and engineers. Portland cement was invented in England in the 1820 s but by the end of century the technological cutting edge of the industry shifted to the United States and Germany, the co-leaders of the Second Industrial Revolution. In 1886 when a Montreal chemist, Thomas M. Morgan, went into partnership with a local businessman to produce Portland cement in Canada, his first step was to study new state-of-the-art plants being set up at the same time in the United States. In 1907 the company was sold to American interests and in 1909, it became part of what would become the dominant firm in the industry - Canada Cement. A group of Philadelphia capitalists bought a Canadian Portland cement plant in Marlbank, Ontario in 1898 and replaced the older style kilns with American rotary kilns. Canadian R.P. Butchart, another principal player in the Canada Cement merger, and the first person to build a cement factory in Western Canada, also installed American continuous process rotary kiln technology which by the early twentieth century was the Canadian standard. William Foster Cowham, an American expert in the field, constructed Portland cement factories in several US states as well as Ontario and Quebec. His system made extensive use of mechanized process control and electricity, hallmarks of Second Industrial Revolution production. As Chandler has explained, it was the large, managerially-intensive oligopolistic modern corporation which was best able to exploit these new technologies (and, though Chandler would not say this, to encompass the social relations of production). ${ }^{18} \mathrm{By}$ the first decade of the twentieth century, however, productive capacity in the Cana- 
dian cement industry was fragmented among a large number of mostly small firms, some Canadian-owned and some branch plants of US firms, established in Canada to evade Canadian tariffs. In 1909 Joseph Irvin, who had been instrumental in introducing Cowham's technology into Canada, met with financier Max Aitken and arranged the merger which created Canada Cement. The financial chicanery involved led, of course, to Aitken leaving the country with his ill-gotten gains. ${ }^{19}$

The Second Industrial Revolution, with its concomitant rise of sciencebased industry, was the era when the United States surged ahead in world economic leadership as well as in establishing itself as an imperial power. ${ }^{20}$ To some extent the increasingly integrated Canadian economy was simply carried along. But Marvin McInnis has gone so far as to suggest that "Canada was arguably the most successful exploiter of the new technology of the Second Industrial Revolution." ${ }^{21}$ If this was just a story of a one-way technological spill-over from the United States, it would be a simple one of limited interest. That was not the case, and we need neither celebrate Yankee know-how nor stand in awe of American technological sublimity. ${ }^{22}$ Some Canadian firms sold goods or, more rarely, acquired production facilities in the United States. Occasionally Canada even managed to stay ahead of the US in its production practices. Significant technological developments originated north of the border. For example, Nova Scotia geologist Abraham Gesner developed the earliest method of distilling kerosene (which he named) from coal. Union Carbide bought the patent for the efficient production of calcium carbide (to make acetylene) from Canadian Thomas Wilson. The commercial pumping of North American petroleum was underway in southwestern Ontario shortly before it was in Pennsylvania. McBryde has referred to facilities in Ontario as a "Pilot Plant for the Chemical Refining of Petroleum in North America." 23 For a time the Canadian system of rotary drilling rivalled the American system of percussion cable-drilling in the international petroleum industry. ${ }^{24}$ As Winder has carefully documented, farm equipment producers in Canada and the United States through patenting and licensing arrangements created, contributed to, modified, and drew from what can best be described as a common North American pool of technology. ${ }^{25}$ What can we make of the origin of the Jordan Spreader, an important piece of railway maintenance equipment? It was invented by Oswald F. Jordan, a superintendent with the Canada Southern Railway in St. Thomas, Ontario. The Canada Southern was itself a division of the New York Central Railway and Jordan himself moved to Chicago where he established production facilities for his device, which was sold to railways in both Canada and the United States, custom built for each line. ${ }^{26}$ Perhaps the most revealing case, however, comes from the industrialization of food production. During the 1880s and 1890 s American cheese makers engaged in a ruinous race to the bottom with cost and corner-cutting production shortcuts. In Canada, however, export regulations constrained and restrained producers from such practices. As a result, the United States lost much of its export market for cheese to Canadian producers. This left the New York and Wisconsin cheese industries to play catch- 
up after state governments knocked heads together in the respective dairy industries in a classic instance of the regulatory state trying to save businesspeople from the consequences of their own greed. It is indeed a remarkable instance of US state agents working to compel private US industry to raise production standards up to those prevailing north of the border. ${ }^{27}$

The Second Industrial Revolution also featured the intensification of scientific research for and by industry. While in-house research by science-intensive giants like Du Pont, Westinghouse, GE, and Bell Labs has attracted the most scholarly attention, this was only one part of a much broader involvement in scientific industrial research. Industrial research also involved programs of investigations that brought together small, medium, and large firms; universities; and public agencies. They also brought together researchers on both sides of the continental border as the following two examples show. Tests on the endurance properties of steel rails, sponsored by the US National Bureau of Standards, used data from both the Baltimore and Ohio Railroad and the Canadian Pacific Railway. ${ }^{28}$ A committee doing fundamental work on the characteristics of various fatty oils (example specific gravity, flash point) had representatives of the US Department of Agriculture and private firms such as Armour and Swift in the US as well as Canada Packers. ${ }^{29}$

\section{Technological Dialogue}

Rather than speaking of technological transfer from US to Canadian industry as part of some triumphalist narrative of American technological supremacy, it would be much better to use Arnold Pacey's concept of a technological dialogue. Such a concept downplays the initial transfer of a technology in favour of greater attention to the response to it, modification of it, and reciprocal influences. ${ }^{30}$ As Bruce Sinclair notes, Canadians did value and prefer American technology, as it was "so successful and so easy to import." ${ }^{11}$ But as he also notes, there was more to Canadianizing American technology than painting a maple leaf on imported machinery patterns. Canadians did not passively adopt US technology but rather adapted it to local social and economic conditions. Peter J. Wylie, in a careful analysis of technical change in Canadian manufacturing in the first three decades of the twentieth century, shows that "Canadian manufacturers did not use U.S. technology in unaltered fashion, but adapted it to be more cost efficient under Canadian factor market conditions." 32 One of the most nuanced discussions of such a dialogue is Dianne Newell's study of mining and refining technology in Ontario. The largest part of that technology originated in the United States but its implementation "inevitably involved Canada in experimentation, modification and improvement to suit local conditions and solve bottlenecks." 33 The improved diamond drill of the New York City firm of Severance \& Holt was introduced into the lead mining industry of Missouri in 1869 and Colorado's silver mining industry the following year. By 1873 it was in use in Ontario's silver mining industry. New stamping machines to crush ore developed in California mining camps in the 1850s and further improved 
in the copper district of Lake Superior then spread swiftly through the Canadian mining industry. But a particularly instructive case is the vanner, a type of inclined gravity shaker used in ore separation. A version was popular in the Michigan copper region in the 1870s. A former Michigan mining captain, William Bell Frue, and a New York mechanic, William Foster, developed the definitive version while working at the Silver Inlet Mine in Ontario. Manufactured by a Chicago firm, Fraser and Chalmers, it gained international use. In this context it is also significant that labour (and labour organization) was transnational. James Otto Petersen has described the importance of labour in technological innovation in the Ontario mining industry. ${ }^{34}$

As the case of the Frue vanner suggests, the role of individuals as carriers of technological knowledge must not be neglected. With few restrictions on movement or even immigration across the Canada-US border in this period, individuals carried technical knowledge in both directions. Canadian engineers occasionally complained about competition from US engineers and tried with limited success to gain protection through government-enforced occupational licensure. ${ }^{35}$ They were in fact the beneficiaries of the easy movement of engineers to projects on either side of the border. The Hoosac Tunnel, hailed by David Nye as an icon of the American technological sublime, was in fact completed by Canadian engineers Walter and Francis Shanly. ${ }^{36}$ Canadian Thomas Keefer, like so many North American engineers of his generation, got his first training working on the Erie Canal. After a long and successful career mostly designing municipal waterworks in Canada, he was elected President of the American Society of Civil Engineers. ${ }^{37}$ Knowledge gained in the universities of one country found applications in the industrial plants of the other. Ontario-born John Bates did his undergraduate training at Acadia University in Nova Scotia before going to the United States. He worked with the Arthur D. Little Company in Boston and a New York paper company while studying for the first PhD in Chemical Engineering awarded by Columbia University in 1914. He returned to Canada to a long and successful career in the Canadian pulp and paper industry. ${ }^{38}$ Frederick Mark Becket earned his electrical engineering degree at McGill University in 1895 and also did graduate work at Columbia. He went on to work in the Niagara Falls electrochemical industry and became head of Union Carbide's research laboratories. ${ }^{39}$ These are only some of innumerable examples.

Technology is, of course, more than just hardware and productive practices at work. One way in which shop floor practices were transformed in the Second Industrial Revolution was via the redesign of work processes by engineers, that is, Taylorism or scientific management. The shops of the major Canadian railroads, which manufactured many of their own cars and locomotives, had long emerged as the most sophisticated and among the largest sites of secondary manufacturing in the country. ${ }^{40}$ Taylorist scientific management techniques, for example, crossed the border when Henry Gantt brought them to the Canadian Pacific Railway's Angus Shops in Montreal where most of the railroad's rolling stock was manufactured. $^{41}$ 
The other important way in which control over production at the factory floor level changed was the growing reliance, not on individual human sensory judgement, but instead on a panoply of testing and control instruments. A variety of devices, "epistemic engines" Patrick Carroll-Burke calls them, interrogated the physical state of materials being transformed in production and formed the basis for process control decisions. ${ }^{42}$ Giving a spurious veneer of scientific objectivity to the control of work processes, they were in fact vital weapons in the shop floor wars to wrest control away from workers. ${ }^{43}$ These instruments were usually, but not always, manufactured by American companies. Westinghouse pressure gauges, Brown pyrometers and flow meters, and Tycos recording thermometers were found in plants and mills throughout North American industry.

The pulp and paper industry, however, offers a striking example of such an "epistemic engine" which was developed first in Canada and then migrated across the continent. In making pulp, one of the factors that must be controlled is freeness, the rate at which water drains away from the pulp as it forms into paper. In the 1920s the Canadian Forest Products Laboratories (FPL), located at McGill University, created a freeness tester to measure this property. Such a device was useful both for the investigation of the pulping and papermaking processes in industrial research laboratories and for process control in the mill. ${ }^{44}$ Unsurprisingly, the Canadian tester became the standard for use in Canada. In the US, the Technical Association of the Paper and Pulp Industry's Committee on Groundwood Pulp conducted investigations of several freeness testers before settling on the FPL's, citing the Laboratories' "excellent piece of work." 45 The tester, which found wide acceptance in mills on both sides of the border, "was a powerful means of encouraging additional technical cooperation between the mills." 46 In more formal language, it made of them what Joseph O'Connell has termed a "material collective," which he defines as "a community of persons and institutions mutually exchanging the same representations and material representatives for abstract scientific entities." ${ }^{\prime 7}$

\section{Organizing Industry for Production}

The importance of trade associations in the promotion of technical uniformity in North American industry cannot be exaggerated. The work of Alfred D. Chandler, Jr. and those who have built upon his approach has focused great attention on the actions of modern corporate enterprises. However, the success of this new business history paradigm has caused many historians to overlook the significance of transfirm, industry wide organizations. ${ }^{48}$ This is unfortunate because it neglects the socalled secondary organization of industry as an important alternative strategy of capital seeking security and predictability outside of a Smithian and Darwinian marketplace. It is doubly unfortunate because this strategy is one, unlike that described by Chandler et al., which very much involved the regulatory state as a partner with business. Two examples of pulp and paper and concrete best serve to illustrate the importance of trade associations. 
One of the most explicit and successful cases comes from pulp and paper. The industry itself was economically integrated. Canadian timber was harvested by both US and Canadian firms, processed into pulp in both countries, and both pulp and finished paper products were sold across the border. The US-based Technical Association of the Paper and Pulp Industry (TAPPI) and the Technical Section of the Canadian Pulp and Paper Association (CPPA) committed important resources of time and energy to the issue of technical uniformity. Their most ambitious effort was a series of textbooks codifying existing technical practice in the industry. In September 1918 the Committee on Education of the CPPA along with the Committee on Vocational Education of TAPPI met in Buffalo, New York. They established a Joint Executive Committee to supervise the production of a series of textbooks on pulp and paper manufacture, what became The Manufacture of Pulp and Paper. The initial budget of US $\$ 30000$ was later raised to US\$57 000 and was shared about 60:40 between Americans and Canadians. Royalties would be used to support revisions. Eventually appearing in five volumes, it has been continually revised and, with changes in title, is still in use. The textbooks formed a reference source for state-of-the-art technical practice in the industry and was used in educational programs in the United States and Canada. In the case of the latter, we see the role played by the state in picking up part of the overhead cost of training new workers with new knowledge for Second Industrial Revolution industries. We also see how the struggle for shop floor control extended beyond the shop floor. Those new workers with their new knowledge contended, with great success, for positions in the pulp and paper mills with skilled workers with traditional knowledge gained by on-the-job experience. Labour unions, often international ones, were supportive of technical education but vigilant in wanting workers and working class children to derive benefits from it. ${ }^{49}$

A different approach can be seen in the bringing of new reinforced concrete construction technologies to industrial and residential buildings in Canada. In both countries trade associations played important roles in promoting new concrete materials and methods in construction. In the US the National Association of Cement Users (later the American Concrete Institute) founded in 1904 issued recommendations for concrete construction and criticised the American Society for Testing and Materials for being too conservative in its views of concrete. ${ }^{50}$ In Canada, the Canadian Cement and Concrete Association (CCCA), founded five years later, quickly set to work to make recommendations for concrete construction which could be incorporated into municipal building codes. A key player was Gustave Kahn, Director of Trussed Concrete Steel Company of Canada, which helped bring to Canada the system of steel and concrete construction developed so successfully in Detroit by Albert and Julius Kahn. Gustave Kahn was a Vice President of the CCCA and an active member of the committee which drew up the recommendations. ${ }^{51}$ Municipal building codes address both structural issues and also fire safety. The US-based National Board of Fire Underwriters' model fire code formed 
the basis of many municipal fire codes. A revision of the code giving broad approval for reinforced concrete construction marked an important landmark in the use of that material. The adoption of the Underwriter's code was a major recommendation of American Society for Municipal Improvements' Committee on Fire Prevention when their report was presented at the Society's 1918 meeting in Buffalo. That Committee, which reviewed both US and Canadian practices, was chaired by Alcide Chaussé of Montreal, the Honorary Secretary of the Royal Architectural Institute of Canada. ${ }^{52}$ Canadian expertise in pouring a great deal of concrete in cold weather fed back into general North American practice. With the completion of the Panama Canal, Ontario Hydro's Queenston-Chippawa generating station at Niagara Falls was then the largest ongoing civil engineering project in the world. Ontario Hydro civil engineer R.B. Young became a recognized expert on concrete, serving as a Director of the American Concrete Institute and a member of its Winter Concreting Specifications Committee. ${ }^{53}$

The rise of science-based industry during the Second Industrial Revolution drew firms, beginning with the railways, into increasingly exacting programs of standardization. Technical standards were developed and implemented using laboratory tools and the language of science and were important means by which scientific control of production was achieved. Until the creation of the International Standards Organization following the Second World War, standards were developed and implemented almost exclusively on a national basis. In North America, the development of such standards took place in an economic context of the integration of the Canadian and American economies, in particular the manufacturing sectors. To put it simply, US light bulbs had to screw in to Canadian sockets, Canadian prongs had to fit in American plugs and a watt and a volt had to mean close to the same thing in Saskatoon and Tuscaloosa. Perhaps no other single factor was as important in harmonizing US and Canadian industrial practice and making that practice so sophisticated. ${ }^{54}$ Significantly, there was virtually no Canadian participation in any British or "Imperial" standards setting. As with capital flows, this crucial technological development saw Canada shift its attention from London to New York. Perhaps, even more significantly, while US-based engineering and other standards-setting bodies welcomed and indeed expected the participation of Canadian technical experts, I have looked in vain to find a single instance of British national standards bodies involving Canadians in their work. ${ }^{55}$

While historians have paid far less attention to technical standards than they have to, say, patents, standards are ubiquitous and essential. To give a simple illustration, imagine if each model of car had an opening to its gas tank that could only fit nozzles from one company's gas stations. One of the earliest and most important standards organizations, the American Society for Testing and Materials (ASTM), defines a standard or standard specification as "a precise statement of a set of requirements to be satisfied by a material, product, system, or service that also indicates the procedures for determining whether each of the requirements is 
satisfied." ${ }^{, 56}$ Such standards can be internal to a firm. The modern industrial standards movement really got underway with the work of Charles Dudley at the Pennsylvania Railroad starting in 1875. Beyond that, standards can be developed and promulgated by industry trade and technical associations, engineering societies, and organizations whose sole purpose is the development of such standards. They are called consensus standards and emerge out of a combination of laboratory investigation, industry best (or at least wide) practice and discussions - occasionally contentious - among those who would use the standards. While they are not supposed to, standards can be used, particularly by dominant manufacturers, to gain or maintain competitive advantage. They can also be used as a non-tariff barrier to trade. That is exactly what happened with the American Society of Mechanical Engineers Boiler Code, one of the most important of all such standards. Only in the US and Canada was there an infrastructure to accredit manufactured boilers as meeting the requirements of that code and without such accreditation a boiler essentially could not be sold..$^{57}$ Where a common standards regime prevailed, this pre-empted standards use and probably benefited consumers, though such benefits are difficult to quantify. While much is made of the voluntary nature of standards activity, such a view, on the part of those creating the standards, is disingenuous. They are coercive and can, and indeed in many instances are intended to, become requirements. This could happen in a number of ways. As in the case of steam boilers, insurance companies can require the meeting of a standard for an item, meaning that one which does not will be uninsurable and thus commercially pointless. Also, a standard could become so widespread that being a holdout is economically ruinous. More to the point, standards get written into contracts and then are enforced legally. Finally, standards are used by governments in regulatory activities (as with, for instance, building codes) and thus acquire force of law.

In their practices many Canadian firms simply used US standards. Among the biggest purchasers of the rights to reprint ASTM standards, on par with Carnegie Steel, was the Steel Company of Canada ${ }^{58}$ Even public roads in Canada were built using US technical standards. For example, an Ontario Department of Public Works contract specified that cement and pipes were to be to ASTM standards, and asphalt, according to technical information published in the Journal of the American Chemical Society. ${ }^{59}$ Both Canadian subsidiaries of US firms and domestically owned companies advertised their adherence to US technical standards. Thus the Canadian Ohio Brass Company and the T. McAvity \& Sons company, the latter a Canadian brass and iron products manufacturer, both assured their customers in their marketing literature that they produced to ASTM standards. ${ }^{60}$ Canada had its own standards infrastructure, centred on the Canadian Engineering Standards Association (CESA, later simply renamed the Canadian Standards Association or CSA by which name it is known now). In fact, even nominally made-in-Canada standards were either identical or closely conformed to US ones. One of the first CESA standards was that for steel railway bridges. The Association's justification for how it 
arrived at that standard is worth quoting at some length:

In view of the obvious desirability of agreement between a Canadian specification of this kind and similar documents prepared by authoritative bodies in the United States, the Sub-Committee and the Sectional Committee have carefully considered the bridge specifications of the American Railroad Engineering Association and the specifications for bridge materials issued by the American Society for Testing Materials. It is believed that the specification in its present form, while not in absolute agreement with the American specifications on all points, will be found to be in substantial agreement therewith, the principal points of difference being such as are found desirable in order to comply with Canadian conditions. ${ }^{61}$

This occurs again and again in the formulation of CESA standards. When the Bell Telephone Company of Canada suggested the need for standards for galvanized steel wire CESA obliged. But in the resulting standard, the winding of the wire strands conformed to the practices of American Telephone and Telegraph and the ASTM, while a chemical test that was part of the standard complied with that of the important US trade association, the National Electric Light Association. ${ }^{62}$ It should be noted though that this was not simply a case of a spill-over of US technology into Canada. Canadian engineers frequently served on standards setting committees of US organizations and were thus involved in the creation of those US technical standards which were applied in Canadian industries.

A variety of other motivations, each involving both private interests and the state, brought US and Canadian technological practices together. These included taxation and regulation as well as safety and public health. A method developed by Federal government scientists and engineers at the Pulp and Paper Research Institute of Canada for estimating sulphite content of newsprint, significant inter alia to application of duties, was by the 1930s a standard in the US and Canada, being adopted by the trade associations of both countries. ${ }^{63}$ Two researchers at the laboratories of the Canadian Inland Revenue Department published a paper in the Journal of the American Pharmaceutical Association on the analysis of a type of bark used for medicinal purposes. Their discussion made a number of references to the US Pharmacopeia and the official nature of the analytical work. But they thanked Dr. J.M. Francis of Parke and Davis of Detroit for supplying samples and information. ${ }^{64}$ Even more significant was cooperative work in the area of the healthfulness of food. The much-studied Pure Food and Drug Act of 1906 has been seen by historians as a classic piece of progressive era legislation. Framed in the public interest (as indeed it was) it was supported by, and more specifically in, the interests of big food and pharmaceutical firms which welcomed government involvement and regulation, preferably at a national level. It was also welcomed by the chemists, engi- 
neers, and others who would frame, implement, and administer such national regulation. In fact this had an international dimension. As networks of cold storage facilities developed with the industrialization of food in North America, raising new questions about the healthfulness of food, the American Public Health Association (APHA) worked to develop information on the topic. Dr. Peter H. Bryce, Chief Medical Officer of the Canadian Department of the Interior, was "in some measure responsible for bringing the importance of refrigeration as an economic, social and health necessity" before the APHA in $1911 .{ }^{65}$ He was later a member of the Association's Committee on Cold Storage. ${ }^{66}$ Both Bryce and Dr. Charles J. Hastings, the Toronto Medical Officer of Health, served terms as President of the APHA. The Association also worked to develop standard methods for examining milk, a crucial public health issue and one vital for the development of the dairy industry during a period of rapid urbanization. In 1906, the APHA established a committee to look into standard methods for examining milk. It began by surveying by circular letter practices in the US and Canada. The committee made a progress report at its meeting in Manitoba in 1908 and standards were published in $1910 .{ }^{67}$

\section{Conclusion}

The $49^{\text {th }}$ parallel was also a paradox. It both mattered and did not matter. Technical knowledge, like investment, flowed very easily across that border and technical practices which made sense in one country typically made equal sense in the other. And yet there was a border. The general economic integration of the continental economy showed the same paradox. Both countries maintained high tariff regimes during the last third of the nineteenth and first half of the twentieth century and yet saw a volume of goods cross that border in tremendous quantity. Canada in particular used such a policy with the stated intention of avoiding economic integration and the accompanying danger of political integration. Yet as a consequence of American firms jumping the Canadian tariff wall to create manufacturing capacity in Canada, their smaller neighbour's secondary manufacturing sector came to consist in large measure of branch plants of US firms. Such integration came because of, and not in spite of, the tariff. The flow of technical knowledge across the border was facilitated by that situation and by the easy movement of people with technical knowledge in both directions and other informal mechanisms. But because there was a border and separate legal jurisdictions it meant that special institutional frameworks were needed to implement technical coordination. This included public agencies as well as a variety of technical, professional, and engineering standards and trade associations.

The seeming paradox of economic integration occurring in a framework of nationalistic, protectionist economic strategies might be resolved by seeing this as an instance of what Dani Rodrik has called "smart globalization," the selective removal or maintenance of trade barriers to achieve particular domestic economic (and political) goals. While Rodrik has mostly looked at the post-Second World War 
experience, Andrew Smith and Dimitry Anastakis have shown how this concept applies well to Canadian business and economic history of an earlier period, a view supported by this study. ${ }^{68}$

The establishment of US industrial production and concomitantly US industrial technology in Canada was the most obvious way in which a common technological practice was established in the two countries, but it was not the only one. Historiography has focused on the evils (or, depending on the historian's ideological predilections, virtues) of large corporations and either clashes between or connivance among such corporations and government. This overlooks the crucial role of secondary organizations of industry. Politically contentious forms of corporate concentration and tariffs bedevilled or enlivened the histories of Canada and the United States in the later nineteenth and early twentieth centuries. But the educational and standards activities of trade associations, when they were even noticed, escaped popular, judicial, legislative, and regulatory censure when they did enjoy approbation or encouragement. The most important, though not the only, role of the State in this instance was not directive but permissive. 


\section{NOTES}

${ }^{1}$ A version of this paper was presented in a session on North American Science at the annual meeting of the Canadian Society for the History and Philosophy of Science in Victoria, British Columbia in May 2013. I thank the participants at that session for their questions and comments.

${ }^{2}$ Editorial Canadian Standards Association Quarterly Bulletin 23.3 (October 1949): 1-2.

${ }^{3}$ Peter Botticelli, "Rolls-Royce and the Rise of High-Technology Industry," in Creating Modern Capitalism, ed. Thomas K. McCraw (Cambridge: Harvard University Press, 1997), 94-132.

${ }^{4}$ John Herd Thompson and Stephen J. Randall, Canada and the United States: Ambivalent Allies (Athens, GA: University of George Press, 1994).

${ }^{5}$ The classic study of this new middle class is Burton J. Bledstein, The Culture of Professionalism: The Middle Class and the Development of Higher Education in America (New York: Norton, 1976).

${ }^{6}$ Cf R.T. Naylor, The History of Canadian Business, 1867-1914 (Toronto: J. Lorimer, 1975).

${ }^{7}$ Gabriel Kolko, The Triumph of Conservatism: A Reinterpretation of American History, 1900-1916 (New York, NY: The Free Press, 1963).

${ }^{8}$ Ellis Hawley, "Three Faces of Hooverian Associationalism: Lumber, Aviation, and Movies, 1921-1930," in Regulation in Perspective, ed. Thomas K. McCraw (Cambridge: Harvard UP, 1981), 95-123.

9 Tom Traves, The State and Enterprise (Toronto: University of Toronto Press, 1979).

${ }^{10}$ Walter LaFeber, The New Cambridge bistory of American foreign Relations Vol. 2 (Cambridge, Cambridge University Press, 2013), 204. Canadian scholars have been extremely interested in this development, usually, though not inevitably, critical of successive Canadian governments' policies which in the main facilitated this movement of capital. A good bibliography of the classic literature on this topic is given in the "Selected Bibliography" for chapter 9 in William L. Marr and Donald G. Paterson, Canada: An Economic History (Toronto: Gage, 1989).

11 The following discussion is based on H.V. Nelles, The Politics of Development (Toronto: Macmillan, 1974). For more recent interpretations see the chapters by Dilley, Kuhlberg and White in Andrew Smith and Dimitry Anastakis, Smart Globalization: The Canadian Business and Economic History Experience (Toronto: University of Toronto Press, 2014).

${ }^{12}$ G.P. de'T. Glazebrook, A History of Transportation in Canada (Ryerson: Toronto, 1938). 
${ }^{13}$ Classic descriptions of these phenomena are found in the articles by Drache and Bliss in Ian Lumsden, ed., Close the $49^{\text {th }}$ Parallel Etc. The Americanization of Canada (Toronto: University of Toronto Press. 1970).

${ }^{14}$ Andre Siegel and James Hull, "Made in Canada!' The Canadian Manufacturers' Association's Promotion of Canadian-Made goods, 1911-1921," Journal of the Canadian Historical Association 25.1 (2014): 1-32.

15 Stephen A. Zeff, Forging Accounting Principles in Five Countries: A History and an Analysis of Trends (Champaign, IL: Stipes Publishing, 1972).

${ }^{16}$ F.T.W (President, Packard Electric Co.) to Filer-Smith Machinery Co 12 December 1928, Archives of Ontario Ferranti Packard Papers MS1205.

${ }^{17}$ Gregory P. Marchildon, "Portland Cement and the Second Industrial Revolution in Canada, 1885-1909," paper presented at the Fifth Canadian Business History Conference, Hamilton, Ontario, 1998.

${ }^{18}$ Alfred D. Chandler, Jr., The Visible Hand (Cambridge: Harvard University Press, 1977).

${ }^{19}$ The sordid tale is told in G.P. Marchildon, Profits and Politics: Beaverbrook and the Gilded Age of Canadian Finance (Toronto: University of Toronto Press, 1996).

${ }^{20}$ For the US and Second Industrial Revolution see McCraw, Creating Modern Capitalism. For the place of the Second Industrial Revolution in American history see Peter Temin, “The Future of the New Economic History," Journal of Interdisciplinary History 12.2 (1981): 179-187.

${ }^{21}$ Marvin McInnis, "Engineering Expertise and the Canadian Exploitation of the Technology of the Second Industrial Revolution," in Technology and Human Capital in Historical Perspective, ed. Jonas Ljungberg and Jan-Pieter Smits (Basingstoke: Palgrave Macmillan, 2005).

22 The sort of thing we get in Elting E. Morison, From Know-How to Nowhere (New York: Basic Books, 1974) or David Nye, American Technological Sublime (Cambridge, MA. MIT Press, 1996).

${ }^{23}$ W.A.E. McBryde, "Ontario: Early Pilot Plant for the Chemical Refining of petroleum in North America,” Ontario History 79.3 (1987): 203-30.

${ }^{24}$ Dianne Newell, Technology on the Frontier (Vancouver: University of British Columbia Press, 1986), 35-6.

${ }^{25}$ Gordon M.Winder, "Technology Transfer in the Ontario Harvester Industry 1830-1900," Scientia Canadensis, 18.1 (1994): 38-88.

${ }^{26}$ The device was eventually inducted into the North American Railway Hall of Fame. See their website http://narhf.org/?p=5497.

Mark William Wilde, "Industrialization of Food Processing in the United States, 
1860-1960," (PhD dissertation University of Delaware, 1988), 175-6.

John R. Freeman, Jr. and Haig N. Solakian, "Effect of Service on the Endurance Properties of Steel Rails," Journal of the Franklin Institute, 207.5 (1929): 693-695.

M.F Lauro et al., "Report of the Oil Characteristics Committee," Oil \& Soap (1937): 215.

Arnold Pacey, Technology in World Civilization (Cambridge: The MIT Press, 1991).

Bruce Sinclair, "Canadian Technology: British Traditions and American Influences," Technology and Culture 20.1 (1979): 108-123.

Peter J. Wylie, “Technological Adaptation in Canadian Manufacturing, 19001929," The Journal of Economic History 49.3 (Sept. 1989): 569-91.

Newell, Technology, 9.

James Otto Petersen, "The Origins of Canadian Gold Mining: The Part Played By Labour," (PhD dissertation: University of Toronto, 1978).

J. Rodney Millard, The Master Spirit of the Age (Toronto: University of Toronto Press, 1988).

Nye, American Technological Sublime; Richard White, Gentlemen Engineers (Toronto: University of Toronto Press, 1999).

H. V. Nelles, "KEEFER, THOMAS COLTRIN," in Dictionary of Canadian Biography, vol. 14, University of Toronto/Université Laval, 2003-.

John S. Bates By the Way (Hantport, N.S.: Lancelot Press, 1983).

Martha Moore Trescott, The Rise of the American Electrochemicals Industry, 18801910 (Westport: Greenwood, 1981).

Paul Craven and Tom Traves, "Canadian Railways as Manufacturers," Canadian Historical Association Historical Papers (1983): 254-81.

Robert Nahuet, "Une experience canadienne de Taylorisme: le cas des usines Angus du Canadien Pacifique” (MA Dissertation: University of Quebec at Montreal, 1994).

${ }^{42}$ This is discussed in Stuart Bennett, "'The Industrial Instrument - Master of Industry, Servant of Management': Automatic Control in the Process Industries, 1900-1940," Technology and Culture 32 (1991): 69-81. Patrick Carroll-Burke, "Tools, Instruments and Engines: Getting a Handle on the Specificity of Engine Science," Social Studies of Science 31 (2001): 593-626.

43 James Hull, "Working with Figures: Industrial Measurement as Hegemonic Discourse," Left History 9.1 (2003): 62-78.

${ }^{44}$ W.G. Mitchell, Review History of Pulp and Paper Research institute of Canada 19251937, McGill University Archives RG2 C66, 25-28.

45 Allen Abrams, "Report on Testing Freeness of Pulp," Paper Trade Journal 84 
(1927) TAPPI Section: 110.

${ }^{46}$ James d'A. Clark, Pulp Technology and Treatment for Paper (San Francisco: Freeman, 1978), 511.

${ }^{47}$ Joseph O'Connell, "Metrology: The Creation of Universality by the Circulation of Particulars," Social Studies of Science 23 (1993): 129-73.

${ }^{48}$ But for a useful overview see Hiroaki Yamazaki and Matao Miyamoto eds.

Trade Associations in Business History: The International Conference on Business History 14; Proceedings of the Fuji Conference (New York: University of Tokyo Press, 1988).

${ }^{49}$ James Hull, "Strictly By the Book: Textbooks and the Control of Production in the North American Pulp and Paper Industry," History of Education 27.1 (1998): 85-95. See also Oisin Patrick Rafferty, “Apprenticeship's Legacy: The Social and Educational Goals of Technical Education in Ontario, 1860-1911 (PhD dissertation: McMaster University, 1995). Rafferty notes how technical education became "a public responsibility at the behest of educators, business and labour leaders alike" (iv).

${ }^{50}$ Amy Slaton, Reinforced Concrete and the Modernization of American Building, 19001930 (Baltimore: Johns Hopkins, 2001), 122-3.

${ }^{51}$ Peter Gillespie et al., "Standard Building Regulations for Reinforced Concrete," Annual Report and Proceedings of the Canadian Cement and Concrete Association 2 (1911): 86-96.

${ }^{52}$ Alicide Chaussé, "Report of the Committee on Fire Protection," Transactions of the American Society for Municipal Improvements 24 (1917-18): 161-171.

${ }^{53}$ See the American Concrete Institute Journal 26 (1930): ii, 904.

${ }^{54}$ An excellent discussion of the importance of standards and specifications but how little historians have noted them is given in Amy Slaton and Janet Abbate, "The Hidden Lives of Standards: Technical Prescriptions and the Transformation of Work in America" in Technologies of Power, ed. Michael Thad Allen and Gabrielle Hecht (Cambridge: MIT Press, 2001), 95-143. On the creation of national markets, standardization, and the need for close control in industry see David C. Mowery and Nathan Rosenberg Technology and the Pursuit of Economic Growth (Cambridge: Cambridge University Press, 1989), 36-37. More formal economic analysis is given in Clarles Kindleberger, "Standards as Public, Collective and Private Goods", Kyklos 36 (1983) and Donald J. Lecraw, "Some Economic Effects of Standards," Applied Economics 16 (1984): 507-22.

${ }^{55}$ James Hull, "Technical Standards and the Integration of the U.S. and Canadian Economies," The American Review of Canadian Studies 32, 1 (Spring 2002): 123-42.

${ }^{56}$ American Society for Testing and Materials, What is ASTM? (West Conshohocken, PA: ASTM, 1999).

${ }^{57}$ For a full discussion see Wilbur Cross, The Code (New York: ASME, 1990). 
58 "Report of Auditors for the Fiscal Year January 1, 1919 to December 31, 1919.” Proceedings ASTM 20.1 (1920): 57.

59 "Specification for Construction of Pavements and Cubing with necessary Drainage on Niagara Boulevard Fort Erie," Ontario Archives of Ontario RG 14153-1 Department of Public Works - Central Registry Files, MS 3905.

${ }^{60}$ For the former see their Catalogue No. 21 (1934) and for the latter their advertisement in The Canadian Engineer, (12 October 1926): 361.

${ }^{61}$ Canadian Engineering Standards Association, "Standard Specification for Steel Railway Bridges," (CESA: Ottawa, 1922): 6.

${ }^{62}$ Canadian Engineering Standards Association, "Standard Specification for Galvanized Steel Wire Strand” B-12 (CESA: Ottawa, 1924).

${ }^{63}$ Annual Report of the Director of Forestry 1931-1932 Library and Archives Canada RG39 v.4 file 46728

${ }^{64}$ L. E. Westman and R. M. Rowat, "The analysis of liquid and aromatic extracts of cascara sagrada, and the introduction of a manganese number for the same" Journal of the American Pharmaceutical Association 7.9 (1918): 759-77.

${ }^{65}$ P. H. Bryce, "Physics of Refrigeration," American Journal of Public Health 2.11 (1912): 829-833.

${ }^{66}$ Ward L. Beebe, Peter H. Bryce, W. F. Snow, and F. D. Bell, " Report of Committee On Cold Storage, American Public Health Association," American Journal of Public Health, 5.5 (May 1915): 458-460.

${ }^{67}$ See the "Historical Introduction" in Standard Methods for the Examination of Dairy Products $11^{\text {th }}$ edition (Washington, D.C.: American Public Health Association, 1960), 1-6.

${ }^{68}$ Dani Rodrik, The Globalization Paradox (New York: Norton, 2011). Smith and Anastakis, Smart Globalization. 


\section{LABOUR/LE TRAVAIL}

\section{Journal of Canadian Labour Studies}

Labour/Le Travail (LLT) is a biannual publication of the Canadian Committee on Labour History. Established in 1976 as an interdisciplinary journal of labour studies, it is Canada's leading forum for articles in working-class history. It also publishes research in other fields, among them: labour economics, industrial sociology, and critical popular culture. An extensive book review and review essay section addresses international work of relevance to Canada. Averaging 350 pages per illustrated issue, LIT's website can be visited at http://www.cclh.ca, with past issues online at www.lltjournal.ca

\section{Canada International}

Individual: 1 Year $\$ 25.001$ Year $\$ 35.00$ 2 Years $\$ 45.002$ Years $\$ 60.00$ 3 Years $\$ 60.003$ Years $\$ 80.00$

Institutional: 1 Year $\$ 35.001$ Year $\$ 55.00$ 2 Years $\$ 60.002$ Years $\$ 95.00$

Student: ${ }^{*} 1$ Year $\$ 15.001$ Year $\$ 30.00$ 4 Years $\$ 50.00 \quad 4$ Years $\$ 95.00$

*This category includes unemployed and retired. All orders will be processed in Canadian dollars.
Send orders with payment to: Canadian Committee on Labour History c/0 Athabasca University Press, Peace Hills Trust Tower $1200,10011-109$ Street Edmonton, AB T5J 358 Canada

Telephone: (780) 421-5062

Facsimile: (780) 421-3298

E-mail: cclh@athabascau.ca

\section{CANADIAN COMMITTEE ON LABOUR HISTORY COMITÉ CANADIEN SUR L'HISTOIRE DU TRAVAIL}

\section{LABOUR/LE TRAVAIL}

\section{Revue d'études ouvrières canadiennes}

Labour / Le Travail (LLT) est une publication semestrielle du Comité canadien sur I'histoire du travail. Créée en 1976 en tant que revue interdisciplinaire d'études ouvrières, elle est devenue le principal instrument de diffusion d'articles sur l'histoire de la classe ouvrière au Canada. On y publie aussi des travaux de recherche dans d'autres domaines, notamment l'économie du travail, la sociologie industrielle et la culture populaire critique. Une importante section consacrée aux comptes rendus d'ouvrages et aux essais critiques recense les travaux internationaux qui présentent un intérêt pour le Canada. Les numéros illustrés de LLT comptent en moyenne 350 pages et peuvent être consultés sur le site Web de la revue, à http://www.cclh.ca. Les anciens numéros sont accessibles en ligne à www.lltjournal.ca.

\begin{tabular}{|c|c|c|c|c|c|}
\hline \multirow[b]{2}{*}{ Particulier: } & \multicolumn{2}{|c|}{ Canada } & \multicolumn{2}{|c|}{ International } & \multirow{2}{*}{$\begin{array}{l}\text { Faire parvenir votre commande } \\
\text { avec le paiement à : }\end{array}$} \\
\hline & 1 an & $25,00 \$$ & 1 an & $35,00 \$$ & \\
\hline & 2 ans & $45,00 \$$ & 2 ans & $60,00 \$$ & Comité canadien sur l'histoire \\
\hline & 3 ans & $60,00 \$$ & 3 ans & $80,00 \$$ & du travail \\
\hline Établissement: & 1 an & $35,00 \$$ & 1 an & $55,00 \$$ & a/s Athabasca University Press, \\
\hline & 2 ans & $60,00 \$$ & 2 ans & $95,00 \$$ & Peace Hills Trust Tower \\
\hline Étudiant/e* : & 1 an & $15,00 \$$ & 1 an & $30,00 \$$ & $1200,10011-10 g^{e}$ Rue \\
\hline & 4 ans & $50,00 \$$ & 4 ans & $95,00 \$$ & Edmonton, AB T5J 358 Canada \\
\hline $\begin{array}{l}{ }^{*} \text { Cette catégori } \\
\text { Toutes les comn }\end{array}$ & $\begin{array}{l}\text { ie englo } \\
\text { mandes }\end{array}$ & $\begin{array}{l}\text { les perso } \\
\text { ont traité }\end{array}$ & es sans & ploi ou retraitées. & $\begin{array}{l}\text { Téléphone: } 780-421-5062 \\
\text { Télécopieur : } 780-421-3298 \\
\text { Courriel : cclh@athabascau.ca }\end{array}$ \\
\hline
\end{tabular}

